\title{
Investigation of Lands Cover Changes with Emphasis on Isfahan Urban Green Space using Manuscripts Tissues, Isfahan, Iran
}

Zahra Ghasemi-Siani ${ }^{1}$, Mojtaba Pirnazar $^{2}$, Saeid Eslamian ${ }^{3}$, Kaveh Ostad-Ali-Askari ${ }^{4}$, Mahboubeh Amoushahi-Khouzani ${ }^{5}$,Maryam Marani-Barzani ${ }^{6}$, Morteza Soltani ${ }^{7}$, Masoud Kazemi $^{8}{ }^{\text {,Nicolas R. Dalezios }}{ }^{9}$,Vijay P. Singh ${ }^{10}$,Yohannes Yihdego ${ }^{11}$, Foroozan Rajaei-Rizi ${ }^{12}$ Shahide Dehghan ${ }^{13}$,Hossein Norouzi ${ }^{14}$,Hamid-Reza Shirvani-Dastgerdi ${ }^{4}$, Arsalan Malekian ${ }^{4}$

${ }^{I}$ Department of Remote Sensing,Yazd Branch, Islamic Azad University, Yazd, Iran.

${ }^{2}$ Department of Remote Sensing, Tabriz University, Tabriz, Iran

${ }^{3}$ Department of Water Engineering, Isfahan University of Technology, Isfahan, Iran

${ }^{4 *}$ Department of Civil Engineering, Isfahan (Khorasgan) Branch, Islamic Azad University, Isfahan, Iran

${ }^{5}$ Water Engineering Department, Science and Research Branch, Islamic Azad University, Tehran, Iran

${ }^{6}$ Department of Geography, University of Malaya (UM),50603 Kuala Lumpur, Malaysia.

${ }^{7}$ Department of Architectural Engineering, Shahinshahr Branch, Islamic Azad University, Shahinshahr, Iran

${ }^{8}$ Civil Engineering Department, Najafabad Branch, Islamic Azad University, Najafabad, Iran

${ }^{9}$ Laboratory of Hydrology, Department of Civil Engineering, University of Thessaly, Volos, Greece \& Department of Natural Resources Development and Agricultural Engineering, Agricultural University of Athens, Athens, Greece.

${ }^{10}$ Department of Biological and Agricultural Engineering \& Zachry Department of Civil Engineering, Texas A and M University, 321 Scoates Hall, 2117 TAMU, College Station, Texas 77843-2117, U.S.A.

${ }^{11}$ Snowy Mountains Engineering Corporation (SMEC), Sydney, New South Wales 2060, Australia. GeoInformation Science and Earth Observation (ITC), University of Twente, the Netherlands

${ }^{12}$ Water Engineering Department, Shahrekord University, Shahrekord, Iran

${ }^{13}$ Department of Geography, Najafabad Branch, Islamic Azad University, Najafabad, Iran

${ }^{14}$ Department of Civil Engineering, Maybod Branch, Islamic Azad University, Maybod, Yazd, Iran

*Corresponding Author: Dr. Kaveh Ostad-Ali-Askari, Department of Civil Engineering, Isfahan (Khorasgan) Branch, Islamic Azad University, Isfahan, Iran. Email: Koa.askari@khuisf.ac.ir

\begin{abstract}
In this research lands cover changes of Isfahan city between 2002 and 2014 period of time accomplished by using satellite images interpretation. In $2002+$ ETM sensor punchromatology band was used and in 2014 OLI-TIRS sensor punchromatology band was used. We used tissues filters in Envit 4.8 software for calculating changes. Lands cover has been extracted according to properties of phenomena's manuscript tissue. Intended area was determined in six lands cover, grass, roads, wastelands, agronomy lands and trees. Ultimate precision in 5*5 average filter for Landsat images have been 79 percent in 2002 and have been 81 percent in 2014. We got the rate of lands cover changes and urban green space with via cross-tab tool in IDRISI software. Urban green space area became from 98319800 meter in 2002 to 57359700 meter in 2014.
\end{abstract}

Keywords: changes monitor, lands cover, manuscripts tissues, Isfahan.

\section{INTRODUCTION}

Availability to field datainorder to changes cover checking out and supervising in global and zonal scale is usually difficult and limited. Using of satellite images is very important because of specific features such as wide view, low costly, using different parts of electromagnetic spectrums to record 
the features of phenomena, short return period, automatic analysis possibility, faster review and providing area supervising possibility. In recent years, high resolution sensors images have been considered one of the new useful results of remote sensing. Intoday`s satellite images spectral changes have increased because of their high spatial resolution. As result variance goes up in each class. This case make classes possible density functions extend and as result make them more overlap, and this case by its own raises the classification error. To have less error in this kind of images we should use their spatial information (tissues information) in addition to spectral information. To achieve to sustainable development, planning accurately, control and management of land control cover changes, that they occurred by natural or artificial factors including human interference, are very necessary. Urban managers and planners are needful a tool that offers information correctly, quickly and betimes. Mokhtary began to check out the impacts of drought on herbal cover changes and Isfahan city green space with Landsat satellite +ETM and TM multiple times images that displays impact of drought in urban control change as well in course desired [1-8].Matinfar and partners examined determination of control type and lands cover by +ETM7 Landsat data by using object-oriented programming methods (Kashan area) Kashan drought areas. Object-oriented programming methods precision is equal to 95 and it can be concluded that object-oriented programming method is assort for checking out drought areas [9-14]. Feizizade and partners studied remote sensing data in revelation of Tabriz urban green space changes and according to obtained 16 years old period results that gained by SPOT and LANDSAT images object-oriented programming classification, shows city green space decreases more than 46 percent in study case period and its capitation achieve from 14 square meter in 1988 to 7.5 square meter in 2005 [15-19]. Abdolalizade predicted about green mountain protected area lands cover future changeswith MARKOV model and conclusion of changes shows that agricultural, bush and forest lands area have increased but herb pastures and bare grounds have decreased [20-25]. Kite and colleagues(2012) in a perusal identified urban poor neighborhood in HeidarAbad, India according to manuscript tissues. Unique features of Slumdog areas are lots of numbers of buildings and small size of houses. Used method to prepare Slumdog areas plan in crowded cities is reliable and it can be used to survey multiple times data in developing cities [26-34]. Gutierrez studied with Object-oriented programming and base pixel combined method to improved classification accuracy in land cover changes survey to recognize changes in a mountainous area in Mexico and the following results was obtained:

Precision comparison for pixel method was equal to 74.0 and 81.0 and for Object-oriented programming method was equal to 71.0 and 77.0 and for Object-oriented programming and base pixel combined method was equal to 88.0 and 87.0 that shows precision increase in combined method [3538]. Srivastava and colleagues used excerpt of remote sensing techniques such as SVM, neural network and most likely classification to survey lands cover changes. Images which used in this research are LANDSAT collection of images. Results demonstrated SVM technique is more suiTable than two others technique. Changes have surveyed in England LANDSAT images by CCDC algorithm since 1982 to 2011 and overall accuracy based on CCDC algorithm was equal to 98.0. Kappa coefficient was equal to 86.0 shows successfully of this algorithm with this level of accuracy [39-45].

\section{Method Materials}

Isfahan is located in south of Tehran and 435 kilometers far from it. Isfahan city has 51 degrees and 39 minutes and 40 seconds eastern longitude and 32 degrees and 38 minutes and 30 seconds northern latitude. Figure (1) is divided to fourteen urban areas and out of urban area is leaded Khomeinishahr and Najafabad from the west, Sofeh Mountainand Sepahanshahr from the south, Shahinshahr from the north and Segzi plain from the east. The red borderline is Isfahan city and the blue borderline is added to illustrate agricultural cover in northeast part. Isfahan city 7Landsat image is in 2002 and Isfahan city 8Landsat image is in 2014. Only panchromatic band of this collection of images is used in Table (1). 

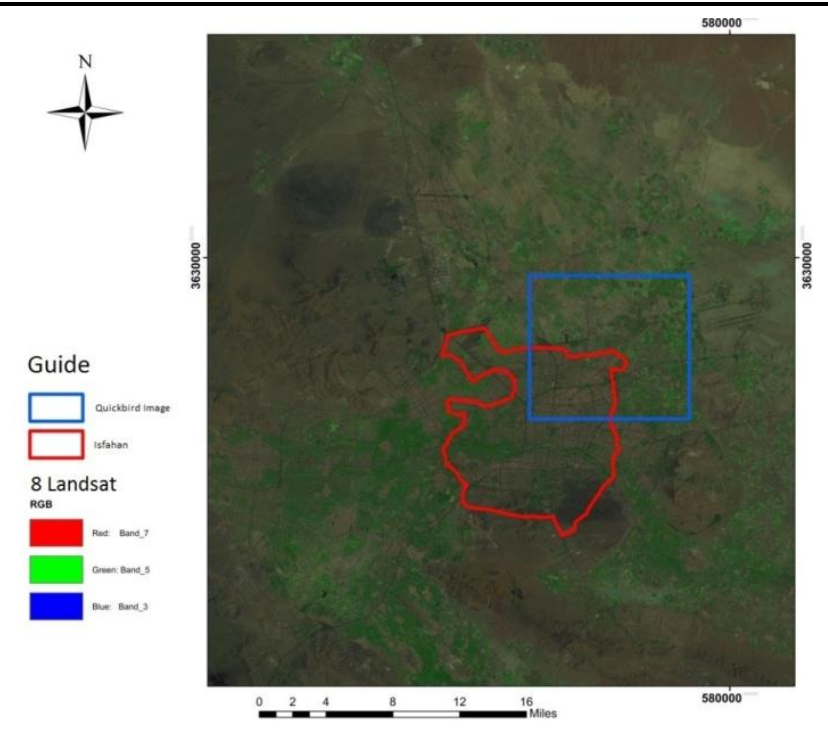

Figure1. Area of Study

Table1. Features of Landsat images

\begin{tabular}{|c|c|c|c|c|c|}
\hline $\begin{array}{c}\text { Radio } \\
\text { metric } \\
\text { resolution }\end{array}$ & $\begin{array}{c}\text { Panchromatic } \\
\text { band spatial } \\
\text { resolution }\end{array}$ & $\begin{array}{c}\text { Path and Row } \\
\text { number of image }\end{array}$ & $\begin{array}{c}\text { Date of } \\
\text { taking } \\
\text { image }\end{array}$ & $\begin{array}{c}\text { Type of } \\
\text { sensor }\end{array}$ & Satellite \\
\hline 8 Bit & 15 Meter & P162,R 39 & 2002 & ETM+ & 7Landsat \\
\hline 8 Bit & 15 Meter & P162,R 39 & 2014 & OLI_TIRS & 8Landsat \\
\hline
\end{tabular}

\subsection{Maximum Possibility Classification}

Maximum possibility classification is one of the most popular methods of statistical classification that is a part of base pixel method. After applying tissue filters on panchromatic band of images and taking training samples, image classifying was performed based on most likely method as it is illustrated in Figure (2) and (3). Then we used Confusion Matrix tool for verification of classification precision and below results was obtained:

Table2. Total precision and kappa coefficient of classified images in maximum possibility

\begin{tabular}{|c|c|c|c|c|}
\hline \multicolumn{2}{|c|}{ Kappa coefficient } & \multicolumn{2}{c|}{ Total precision } & \multirow{2}{*}{ Landite images } \\
\cline { 1 - 3 } $\begin{array}{c}\text { Green } \\
\text { space }\end{array}$ & Lands cover & Green space & 0.55 & 7 Landsat \\
\hline 0.44 & 0.42 & 0.79 & 0.62 & 8 Landsat \\
\hline 0.52 & 0.48 & 0.81 & \\
\hline
\end{tabular}
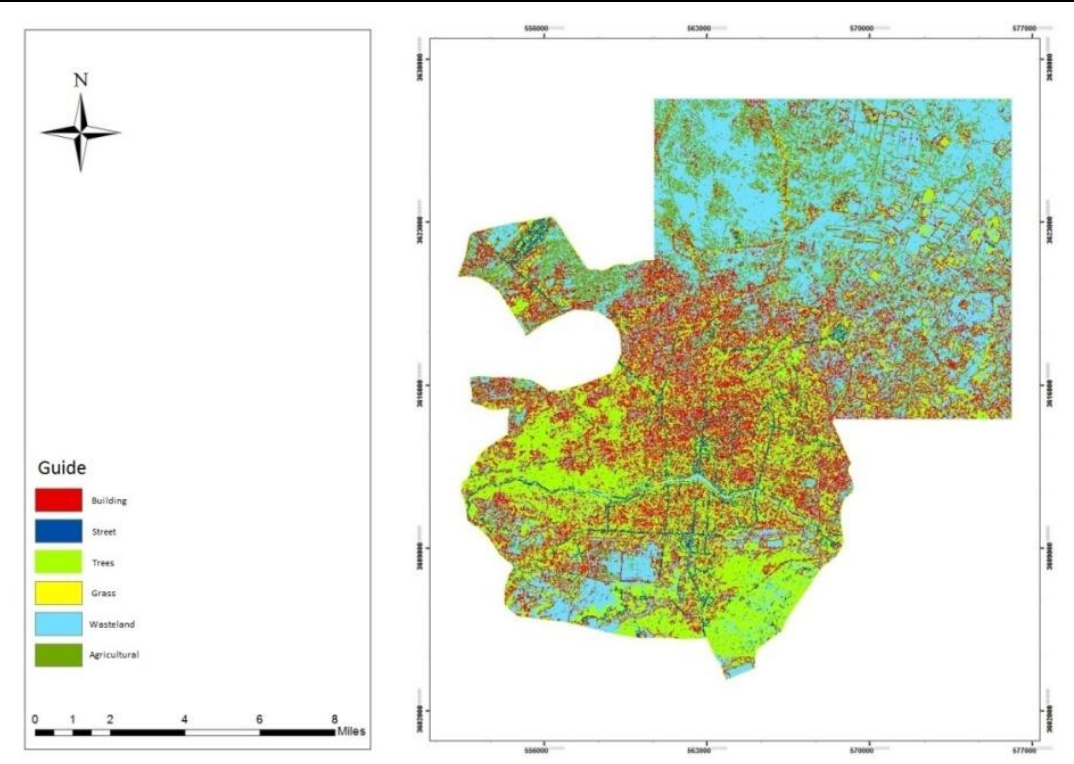

Figure2. Maximum possibility classification in Isfahan 7 Landsat image 

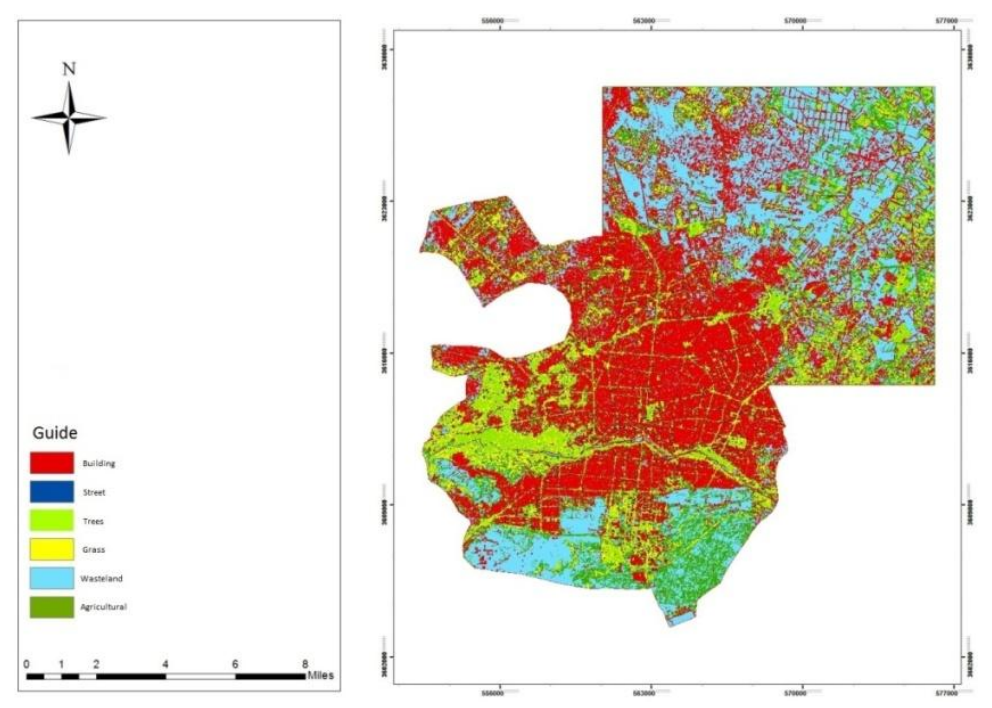

Figure3. Maximum possibility classification in Isfahan 8 Landsat image

\subsection{Average Filter with $3 * 3$ Window Size}

We used average filter with $3 * 3$ window size images to improve. In Figure (4) and (5) the main precision of lands cover reached to 69.62 and Kappa coefficient reached to 0.61 percent and in use of green space main precision equals to 78.0034 and Kappa coefficient increased to 0.66.
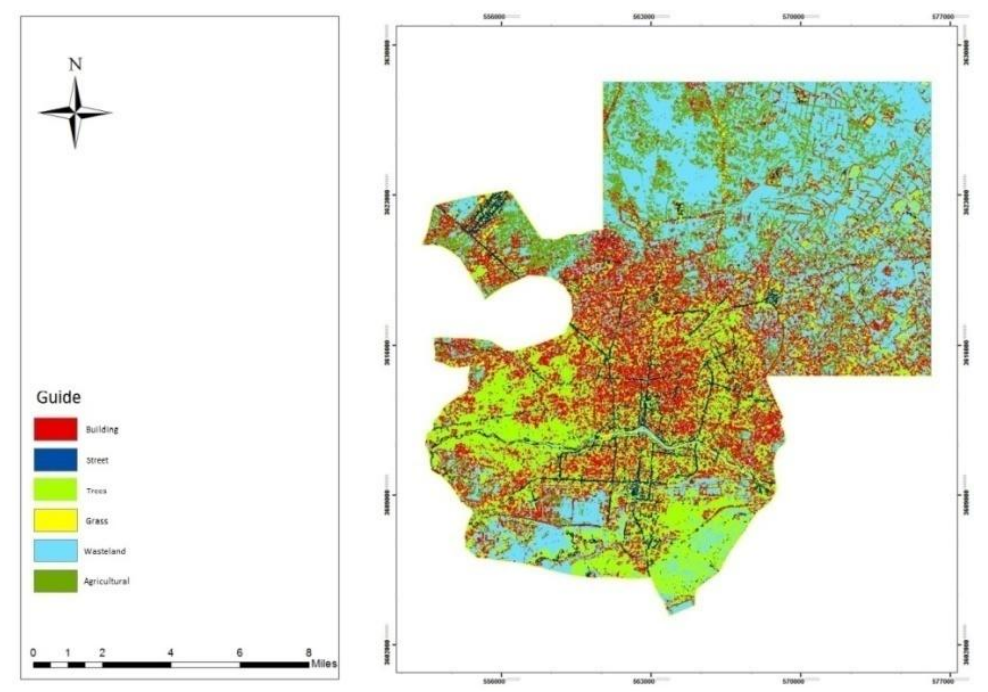

Figure4. Maximum possibility classification in Isfahan 7 Landsat image with $3 * 3$ window size average filter
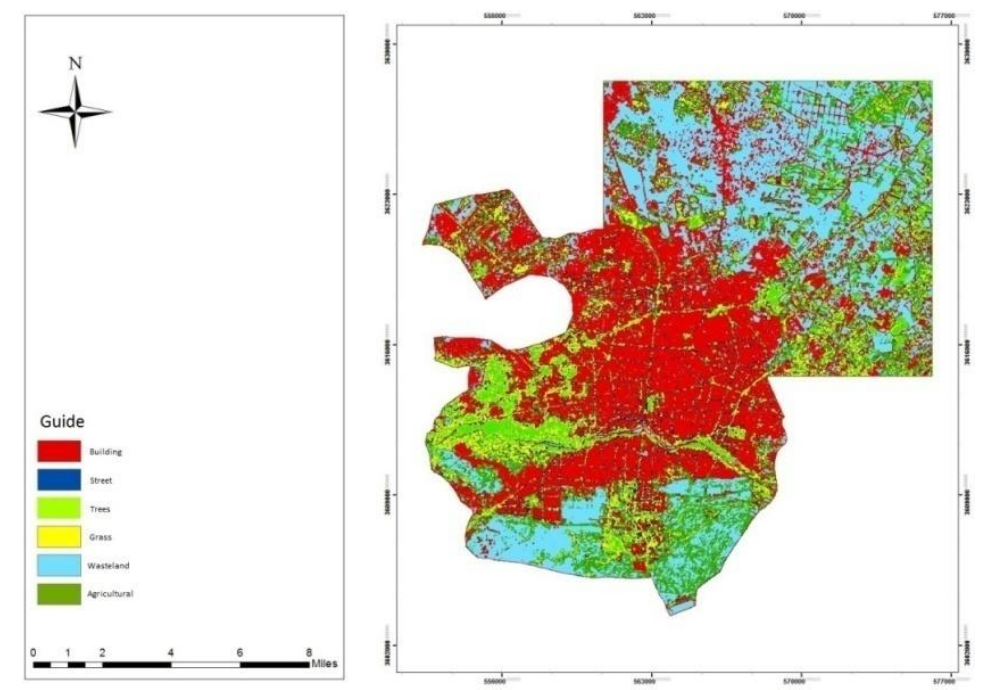

Figure5: Maximum possibility classification in Isfahan 8 Landsat image with $3 * 3$ window size average filter. 


\subsection{Average Filter with $5 * 5$ Window Size}

According to previous step's conclusions and lands cover classification improvement, we applied average filter with $5 * 5$ window size on image and following results were obtained. Total precision for lands cover in 2002 Landsat's image is equal to 64\% and for lands cover in 2014 Landsat's image is equal to $56 \%$. Total precision for urban green space in Isfahan 2002 Landsat's images is equal to $86 \%$ and for 2014 Landsat's image is equal to 89\%. Kappa coefficient for urban green space in 2002 is equal to $64 \%$ and in 2014 is equal to $71 \%$. These conclusions illustrated that average filter with $5 * 5$ window size has considerable impact on accuracy [46-69].
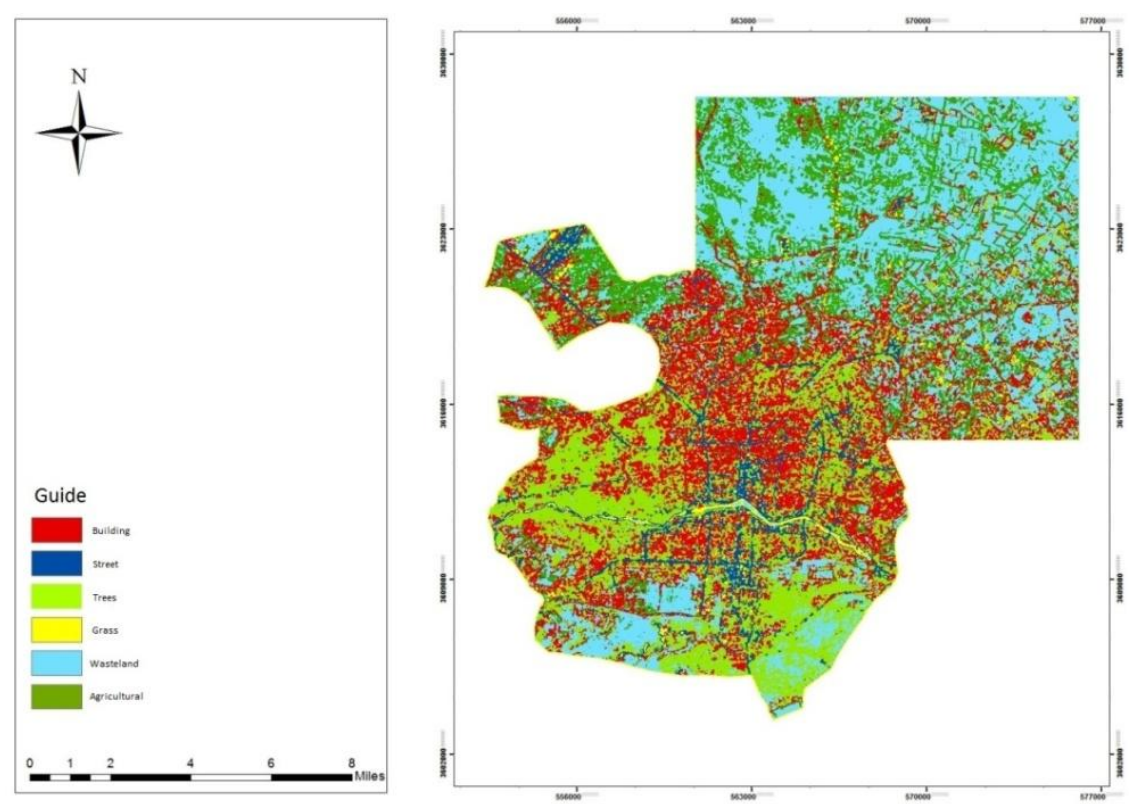

Figure6. Maximum possibility classification in Isfahan 7 Landsat image with $5 * 5$ window size average filter
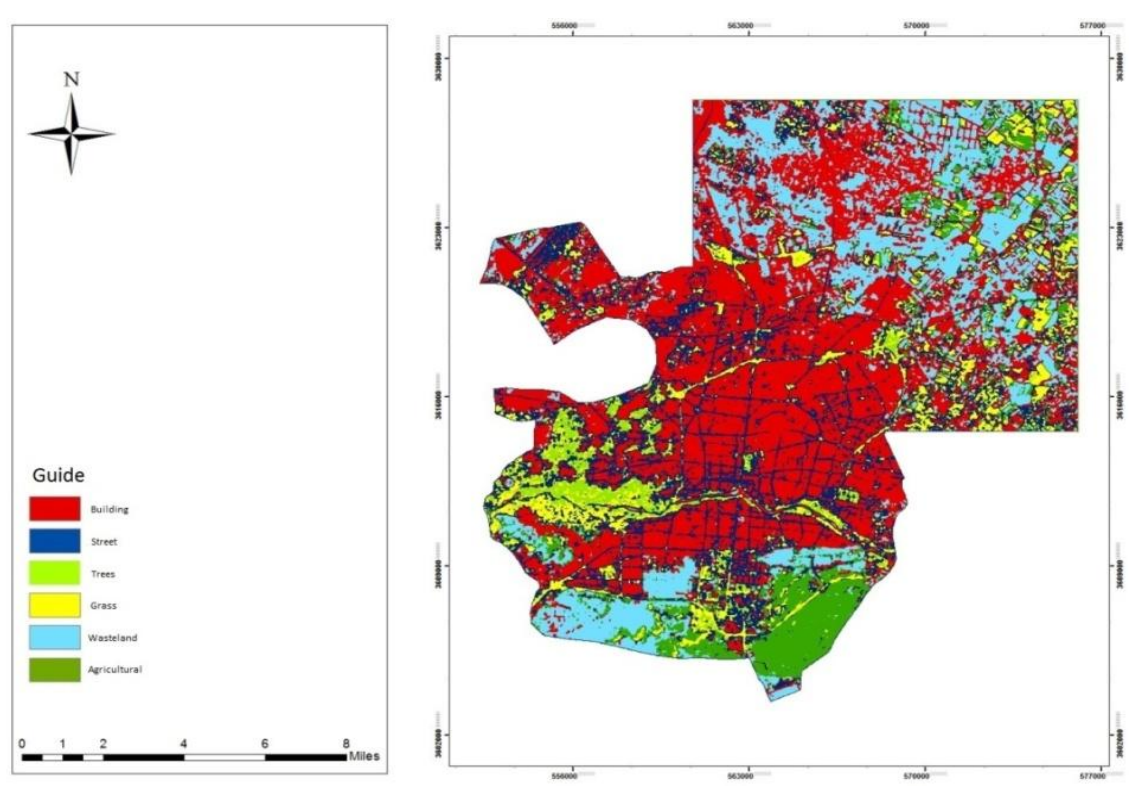

Figure7. Maximum possibility classification in Isfahan 8 Landsat image with $5 * 5$ window size average filter

\subsection{Urban Green Space Durability}

Cross-tab tool in Idris Tiga software has used to obtain change rate. Classified images in Envit4.8 software were converted to Idris Tiga software's file's format. Classified images were imported in cross-tab tool and all classes changes image was calculated (Figure8, Table3). Lands cover changes precision obtained $70 \%$ Kappa coefficient. Green space density in 2002 was equal to 0.25380784 meter and density in 2014 was equal to 13193007 meter. Table (4) illustrate reduction of urban green space. Rate of this change was equal to 12187777.0 meter [70-88]. 
Investigation of Lands Cover Changes with Emphasis on Isfahan Urban Green Space using Manuscripts Tissues, Isfahan, Iran

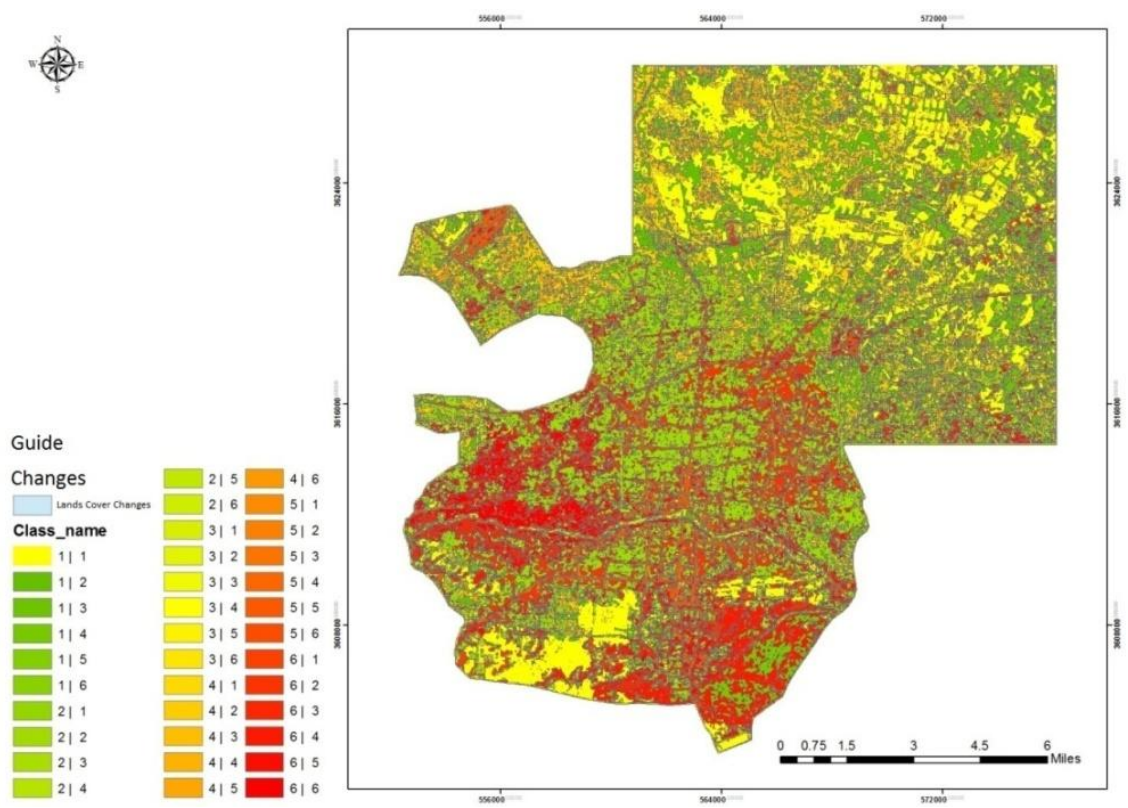

Figure8. Lands Cover Changes Map 2002 to 2014

Table3. Lands cover change area and user to each other

\begin{tabular}{|c|c|c|}
\hline Levels changes area & & Lands cover levels conversion \\
\hline 44.7039 & \begin{tabular}{l|l}
1 & 1
\end{tabular} & Urban to urban \\
\hline 5.5575 & \begin{tabular}{l|l}
2 & 1 \\
\end{tabular} & Urban to street \\
\hline 0.5355 & \begin{tabular}{l|l|l}
3 & 1
\end{tabular} & Urban to trees \\
\hline 13.4118 & \begin{tabular}{l|l}
4 & 1 \\
\end{tabular} & Urban to grass field \\
\hline 0.2052 & \begin{tabular}{l|l}
5 & 1 \\
\end{tabular} & Urban to wasteland \\
\hline 3.9771 & \begin{tabular}{l|l}
6 & 1
\end{tabular} & Urban to agricultural land \\
\hline 39.5271 & \begin{tabular}{l|l}
2 & 2 \\
\end{tabular} & Street to building \\
\hline 61.0731 & \begin{tabular}{l|l}
2 & 2
\end{tabular} & Street to street \\
\hline 5.3379 & \begin{tabular}{l|l}
3 & 2 \\
\end{tabular} & Street to trees \\
\hline 40.2858 & \begin{tabular}{l|l}
2 & 2
\end{tabular} & Street to grass \\
\hline 6.4044 & \begin{tabular}{l|l}
5 & 2 \\
\end{tabular} & Street to wasteland \\
\hline 25.6572 & \begin{tabular}{l|l}
6 & 2
\end{tabular} & Street to agricultural land \\
\hline 6.5151 & \begin{tabular}{l|l}
1 & 3 \\
\end{tabular} & Trees to urban \\
\hline 3.5163 & \begin{tabular}{l|l|l}
2 & 3
\end{tabular} & Trees to street \\
\hline 0.6111 & \begin{tabular}{l|l}
3 & 3
\end{tabular} & Trees to trees \\
\hline 2.4597 & \begin{tabular}{l|l}
4 & 3
\end{tabular} & Trees to grass \\
\hline 1.9008 & \begin{tabular}{l|l}
5 & 3
\end{tabular} & Trees to wasteland \\
\hline 7.8399 & \begin{tabular}{l|l}
6 & 3
\end{tabular} & Trees to agricultural land \\
\hline 8.7021 & \begin{tabular}{l|l}
1 & 4
\end{tabular} & Grass to urban \\
\hline 1.4445 & \begin{tabular}{l|l}
2 & 4
\end{tabular} & Grass to street \\
\hline 0.1647 & \begin{tabular}{l|l}
3 & 4
\end{tabular} & Grass to trees \\
\hline 1.3581 & \begin{tabular}{l|l}
4 & 4 \\
\end{tabular} & Grass to grass \\
\hline 0.2673 & \begin{tabular}{l|l}
5 & 4 \\
\end{tabular} & Grass to wasteland \\
\hline 11.1834 & \begin{tabular}{l|l}
6 & 4
\end{tabular} & Grass to agricultural land \\
\hline 6.1686 & \begin{tabular}{l|l}
1 & 5
\end{tabular} & Wasteland to urban \\
\hline 10.7568 & \begin{tabular}{l|l}
2 & 5
\end{tabular} & Wasteland to street \\
\hline 13.5144 & \begin{tabular}{l|l}
3 & 5
\end{tabular} & Wasteland to tress \\
\hline 21.1383 & \begin{tabular}{l|l}
4 & 5
\end{tabular} & Wasteland to grass \\
\hline 0.0072 & \begin{tabular}{l|l}
5 & 5
\end{tabular} & Wasteland to Wasteland \\
\hline 0.8046 & \begin{tabular}{l|l}
6 & 5 \\
\end{tabular} & Wasteland to agricultural \\
\hline 0.2718 & \begin{tabular}{l|l}
1 & 6
\end{tabular} & Agricultural to urban \\
\hline 0.1989 & $2 \mid 6$ & Agricultural to street \\
\hline 1.0989 & \begin{tabular}{l|l}
3 & 6
\end{tabular} & Agricultural to trees \\
\hline 7.9704 & \begin{tabular}{l|l}
6 & 6
\end{tabular} & Agricultural to grass \\
\hline 1.0989 & \begin{tabular}{l|l}
5 & 6 \\
\end{tabular} & Agricultural to wasteland \\
\hline 799704000 & & Agricultural to agricultural \\
\hline
\end{tabular}




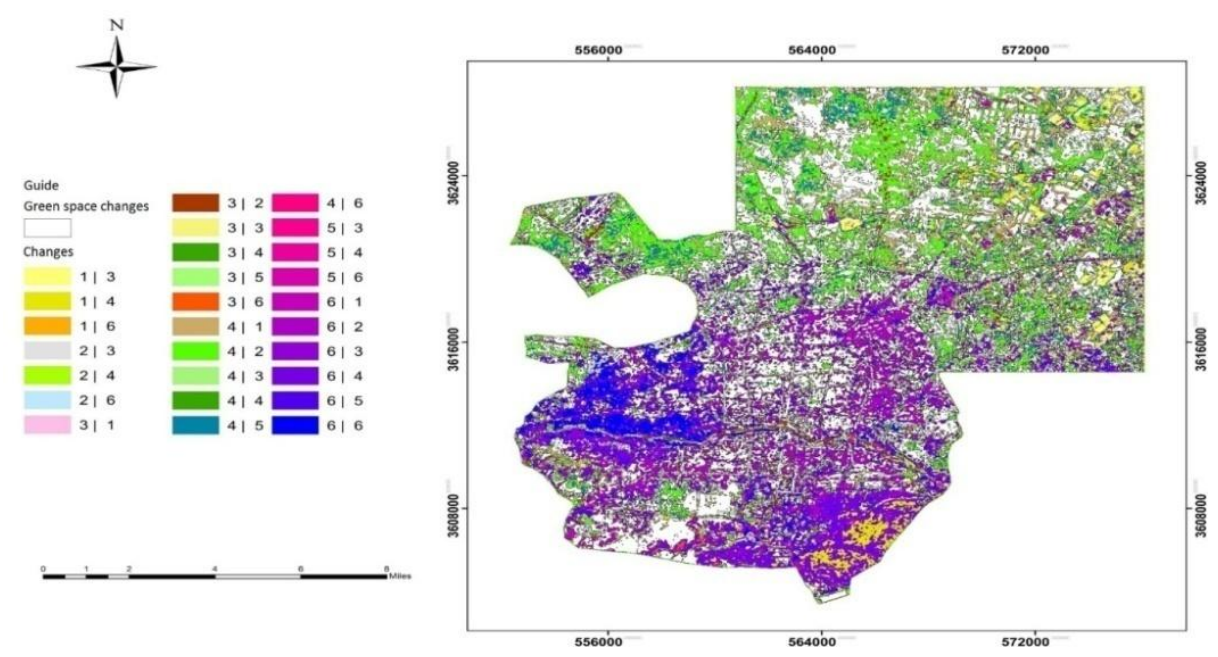

Figure9: Green Spaces Type Changes Map 2002 to 2014

Table4: Lands cover's area change in meters in 2002 to 2014

\begin{tabular}{|l|l|l|}
\hline Image of 2014 & Image of 2002 & Lands cover / user \\
\hline 6844.1400000 & 11201.8500000 & Building \\
\hline 17848.5300000 & 9201.9600000 & Street \\
\hline 2286.4500000 & 1371.2400000 & Trees \\
\hline 2314.0800000 & 6847.1100000 & Grass \\
\hline 8286.3900000 & 2339.1000000 & Wasteland \\
\hline 1135.4400000 & 7776.6300000 & Agricultural land \\
\hline
\end{tabular}

\section{DISCUSSION AND CONCLUSION}

In this research panchromatic band was selected to obtain vegetation change because of higher spatial accuracy than other colored bands. Classification precision of Base Pixel maybe makes a mistake in areas which have various phenomena because of phenomena's spectral diversity. used neural network and automatic cells based on base pixel classification in their research for prediction of urban lands user changes. Instead of using base pixel methods for phenomena's separation and differentiation, features of phenomena such as color, shape, area, tissues and like these can be used. Vegetation has rough and uneven tissue. Because of that, tissue factor was used to separate vegetation in present research used manuscript tissue to classify satellite images. used manuscript tissues information to identify India poor areas [77-81]. used angular tissues information to extract way from satellite images. used a combination of base pixel and Object-oriented programming methods to improve precision of classification for investigation of land cover change of mountainous area in Mexico. In present research after lands cover classification, urban green space was distinguished. After achieving vegetation's map, vegetation's type change, vegetation's area Figure (9) and Table (4) [82-97]. achieved lands user changes durability.

\section{CONCLuSion}

Planning accurately and earth's lands cover changes management and control are necessary to achieve to sustainable development that happened by natural and artificial factors. In present research herbal cover changes investigated by 2002 Lands at images panchromatic band and 2014 Lands at. Panchromatic band has high spatial accuracy and low spectral accuracy. Because of emphasizing on urban green space changes, these changes were obtained based on manuscript tissue are for under uneven of green space are applied on images collection. Obtained Kappa coefficient for changes, shows manuscript tissue has ability to identify herbal cover in panchromatic image.

\section{REFERENCES}

[1] Ostad-Ali-Askari, K., Shayannejad, M. 2015, Study of sensitivity of Autumnal wheat to under irrigation in Shahrekord, Shahrekord City, Iran. International Journal of Agriculture and Crop Sciences, 8 (4), 602-605.

[2] Shayannejad, M., Akbari, N., Ostad-Ali-Askari, K. 2015, Study of modifications of the river physical specifications on muskingum coefficients, through employment of genetic algorithm. International Journal of Development Research, 5(3), 3782-3785. 
[3] Ostad-Ali-Askari, K., Shayannejad, M. 2015, The Reviews of Einstein's Equation of Logarithmic Distribution Platform and the Process of Changes in the Speed Range of the Karkheh River, Khuzestan province, Iran. International Journal of Development Research, 5(3), 3786-3790.

[4] Ostad-Ali-Askari, K., Shayannejad, M., Ghorbanizadee-Kharazi, H. 2015, Assessment of artificial neural network performance and exponential regression in prediction of effective rainfall, International Journal of Development Research, 5(3),3791-3794.

[5] Shayannejad, M. Akbari, N. and Ostad-Ali-Askari, K. 2015, Determination of the nonlinear Muskingum model coefficients using genetic algorithm and numerical solution of the continuity. Int. J. of Science: Basic and Applied Research, 21(1),1-14.

[6] Ostad-Ali-Askari, K., Shayannejad, M. 2015, The Study of Mixture Design for Foam Bitumen and the Polymeric and Oil Materials Function in Loose Soils Consolidation. Journal of Civil Engineering Research, 5(2), 39-44. DOI: 10.5923/j.jce.20150502.04

[7] Sayedipour, M., Ostad-Ali-Askari, K., Shayannejad, M. 2015, Recovery of Run off of the Sewage Refinery, a Factor for Balancing the Isfahan-Borkhar Plain Water Table in Drought Crisis Situation in Isfahan Province-Iran. American Journal of Environmental Engineering, 5(2): 43-46. DOI: 10.5923/j.ajee.20150502.02

[8] Ostad-Ali-Askari, K., Shayannejad, M. 2015, Developing an Optimal Design Model of Furrow Irrigation Based on the Minimum Cost and Maximum Irrigation Efficiency. International Bulletin of Water Resources \& Development, 3(2), 18-23.

[9] Ostad-Ali-Askari K. Groundwater. Horoufchin publisher, First Edition, 2015. ISBN: 978-600-7419-33-5. Isfahan, Iran.

[10] Shayannejad M, Ostad-Ali-Askari K. Modeling of solute movement in groundwater. Kankash publisher. First edition, 2015. ISBN: 978-600-136-256-9. Isfahan, Iran.

[11] Shayannejad M, Ostad-Ali-Askari K. Optimization and its application in water resources management. Kankash publisher. First edition, 2015. ISBN: 978-600-136-248-4. Isfahan, Iran.

[12] Ostad-Ali-Askari K. Nitrate pollution in groundwater. Horoufchin publisher, First Edition, 2015. ISBN: 978-600-7419-23-6. Isfahan, Iran.

[13] Ostad-Ali-Askari, K., Shayannejad, M. 2015, Presenting a Mathematical Model for Estimating the Deep Percolation Due to Irrigation. International Journal of Hydraulic Engineering, 4(1), 17-21. DOI: 10.5923/j.ijhe.20150401.03.

[14] Ostad-Ali-Askari, K., Shayannejad, M. 2015, Usage of rockfill dams in the HEC-RAS software for the purpose of controlling floods. American Journal of Fluid Dynamics, 5(1), 23-29. DOI: 10.5923/j.ajfd.20150501.03.

[15] Ostad-Ali- Askari, K., Shayannejad, M. 2015, The effect of heterogeneity due to inappropriate tillage on water advance and recession in furrow irrigation. Journal of Agricultural Science, 7(6), 127-136.

[16] Shayannejad, M., Ostad-Ali-Askari, K. 2015, Effects of magnetized municipal effluent on some chemical properties of soil in furrow irrigation. International Journal of Agriculture and Crop Sciences, 8(3), 482489.

[17] Ostad-Ali-Askari K, Shayannejad M, Golabchian M. Numerical methods in groundwater. Kankash publisher. First edition, 2015. ISBN: 978-600-136-276-7. Isfahan, Iran.

[18] Ostad-Ali-Askari, K., Shayannejad, M. 2015, Optimal design of pressurized irrigation laterals installed on sloping land. International Journal of Agriculture and Crop Sciences, ISSN 2227-670X. 8(5), 792-797.

[19] Ostad-Ali-Askari K, Shayannejad M, Eslamian S, Jahangiri A.K, Shabani A.H, Environmental Hydraulics of Open Channel Flows. Kankash Publisher. First Edition, 2015. ISBN: 978-600-136-303-0.

[20] Ostad-Ali-Askari K, Shayannejad M, Eslamian S, Navab-Pour B. 2016, Comparison of solution of SaintVenant equations by characteristics and finite difference methods for unsteady flow analyzing in open channel. International Journal of Hydrology Science and Technology, 6(3), 9-18.

[21] Ostad-Ali-Askari K, Shayannejad M, EslamianS, et al. 2017, Deficit Irrigation: Optimization Models. Management of Drought and Water Scarcity. Handbook of Drought and Water Scarcity,Taylor \& FrancisPublisher, USA. Vol. 3. $1^{\text {th }}$ Edition, pp: 373-389.

[22] Eskandari S, Hoodaji M, Tahmourespour A, Abdollahi A, Mohammadian-Baghi T, Eslamian S, Ostad-AliAskari K. 2017, Bioremediation of Polycyclic Aromatic Hydrocarbons by Bacillus Licheniformis ATHE9 and Bacillus Mojavensis ATHE13 as Newly Strains Isolated from Oil-Contaminated Soil. Journal of Geography, Environment and Earth Science International, 11(2): 1-11.

[23] Shayannejad M, Ostad-Ali-Askari K, Eslamian S, et al. 2017, Development of a new method for determination of infiltration coefficients in furrow irrigation with natural non-uniformity of slope. Sustain. Water Resour. Manag., 3(2):163-169. 
[24] Shojaei N, Shafaei-Bejestan M, Eslamian S, Marani-Barzani M, P. Singh V, Kazemi M, Ostad-Ali-Askari K. 2017, Assessment of Drainage Slope on the Manning Coarseness Coefficient in Mountain Area. International Journal of Constructive Research in Civil Engineering (IJCRCE), 3(1): 33-40.

[25] Bahmanpour H, Awhadi S, Enjili J, Eslamian S, Ostad-Ali-Askari K. 2017, Optimizing Absorbent Bentonite and Evaluation of Contaminants Removal from Petrochemical Industries Wastewater. International Journal of Constructive Research in Civil Engineering (IJCRCE), 3(2): 34-42.

[26] Shayannejad M, Eslamian S, Gandomkar A, Marani-Barzani M, Amoushahi-Khouzani M, Majidifar Z, Rajaei-Rizi F, Kazemi M, P. Singh V, Dehghan SH, Shirvani-Dastgerdi H.R, Norouzi H, Ostad-Ali-Askari K. 2017, A Proper Way to Install Trapezoidal Flumes for Measurements in Furrow Irrigation Systems. International Journal of Research Studies in Agricultural Sciences (IJRSAS), 3(7): 1-5.

[27] Dehghan Sh, Kamaneh S.A.A., Eslamian S, Gandomkar A, Marani-Barzani M, Amoushahi-Khouzani M, Singh V.P., Ostad-Ali-Askari K. 2017, Changes in Temperature and Precipitation with the Analysis of Geomorphic Basin Chaos in Shiraz, Iran. International Journal of Constructive Research in Civil Engineering (IJCRCE), 3(2): 50-57.

[28] Eslamian S, Mirabbasi-Najafabadi R, Ostad-Ali-Askari K.Advance Engineering Statistics (Simulation and Modeling of Uncertainty and Sensitivity Analysis). Kankash Publisher. First Edition, 2017. ISBN: 978600-136-359-7. Isfahan, Iran.

[29] Ostad-Ali-Askari K,Shayannejad M. 2016, FLOOD ROUTING IN RIVERS BY MUSKINGUM'S METHOD WITH NEW ADJUSTED COEFFICIENTS. International Water Technology Journal, IWTJ, 6(3): 189-194.

[30] Godarzi A, Eslamian S, Ostad-Ali-Askari K. Water in Literature Aspects (Social and Cultural Aspects). Publication of Tehran Municipality. First Edition, 2016. ISBN:978-600-439-096-5. Tehran, Iran.

[31] Ostad-Ali-Askari K, Eslamian S, Shayannejad M, et al. Groundwater Hydrodynamic. Horoufchin Publisher. First Edition, 2016. ISBN:978-600-7419-53-3. Isfahan, Iran.

[32] Ostad-Ali-Askari K, Shayannejad M, Ghorbanizadeh-Kharazi H. 2017, Artificial Neural Network for Modeling Nitrate Pollution of Groundwater in Marginal Area of Zayandeh-rood River, Isfahan, Iran. KSCE Journal of Civil Engineering, 21(1):134-140.Korean Society of Civil Engineers. DOI 10.1007/s12205-016-0572-8.

[33] Shayannejad M, Ostad-Ali-Askari K, Ramesh A, Singh V.P., Eslamian S. 2017, Wastewater and Magnetized Wastewater Effects on Soil Erosion in Furrow Irrigation. International Journal of Research Studies in Agricultural Sciences (IJRSAS), 3(8): 1-14. http://dx.doi.org/10.20431/2454-6224.0308001.

[34] Shayannejad M, Soltani-Toudeshki A.R, Arab M.A, Eslamian S, Amoushahi-Khouzani M, MaraniBarzani M, Ostad-Ali-Askari K. 2017, A Simple Method for Land Grading Computations and its Comparison with Genetic Algorithm (GA) Method. International Journal of Research Studies in Agricultural Sciences (IJRSAS), 3(8): 26-38.

[35] Mohieyimen P, Eslamian S, Ostad-Ali-Askari K, Soltani M. 2017,Climate Variability: Integration of Renewable Energy into Present and Future Energy Systems in Designing Residential Buildings. International journal of Rural Development, Environment and Health Research(IJREH), 1(2): 18-30.

[36] Shayannejad M, Ostad-Ali-Askari K, Eslamian S, et al. 2017, Flow Hydraulic Investigation of the Wastewater on the Soil and Magnetic Field Effects in This Field. International Journal of Constructive Research in Civil Engineering (IJCRCE), 3(3): 1-15.

[37] Eslamian, S, 2015, (ed.) Urban Water Reuse Handbook, Francis and Taylor, CRC Group, USA, 1141 Pages.

[38] Eslamian, S. S., and S. Tarkesh Esfahani, 2011, Water Reuse (Urban Waste Water Application), Arkan Danesh Publishing, Isfahan, Iran, 327 Pages.

[39] Nazif, S. and Tavakolifar, H., Eslamian, S., 2017, Climate Change Impact on Urban Water Deficit, Ch. 5 in Handbook of Drought and Water Scarcity, Vol. 2: Environmental Impacts and Analysis of Drought and Water Scarcity, Ed. by Eslamian S. and Eslamian F., Francis and Taylor, CRC Press, USA, 81-106.

[40] Dayani, S., Sabzalian, M. R., Hadipour, M. Eslamian, S., 2017,Water Scarcity and Sustainable Urban Green Landscape, Ch. 30 in Handbook of Drought and Water Scarcity, Vol. 2: Environmental Impacts and Analysis of Drought and Water Scarcity, Ed. by Eslamian S. and Eslamian F., Francis and Taylor, CRC Press, USA, 557-604.

[41] Bazrkar, M. H., Zamani, N., Eslamian, S., Eslamian, A., Dehghan, Z., 2015, Urbanization and Climate Change, Handbook of Climate Change Adaptation, Ed. By Leal Filho, W., Springer, 619-655.

[42] Chen, Z., Ngo, H. H., Guo,W, and Eslamian, S., 2015, Water Shortages, in Urban Water Reuse Handbook, Ch. 1, Ed. By Eslamian, S., Taylor and Francis, CRC Group, USA, 3-14.

[43] Boogaard, F. and Eslamian, S., 2015, Water Reuse and Sustainable Urban Drainage Systems, in Urban Water Reuse Handbook, Ch. 4, Ed. By Eslamian, S., Taylor and Francis, CRC Group, USA, 37-44. 
[44] Shah Naqvi, S. A. A., Sultan, A., and Eslamian, S., 2015, Water Quality Issues in Urban Water, in Urban Water Reuse Handbook, Ch. 8, Ed. By Eslamian, S., Taylor and Francis, CRC Group, USA, 99-112.

[45] Kumar Singh, Ch., Jha, N., and Eslamian, S., 2015,Reuse, PoTable Water, and Possibilities, in Urban Water Reuse Handbook, Ch. 9, Ed. By Eslamian, S., Taylor and Francis, CRC Group, USA, 113-126.

[46] Kohansal, M. M., Saadati, S., Tarkesh Esfahany, S., and Eslamian, S., 2015, Urban Water Reuse in Industry, in Urban Water Reuse Handbook, Ch. 11, Ed. By Eslamian, S., Taylor and Francis, CRC Group, USA, 137-148.

[47] Kumar, M., Chidambaram, S.,Ramanathan, A. L., Goswami, R., and Eslamian, S., 2015, Criterion, Indices, and Classification of Water Quality and Water Reuse Options, Urban Water Reuse Handbook, Ch. 13, Ed. By Eslamian, S., Taylor and Francis, CRC Group, USA, 163-176.

[48] Eslamian, F., Eslamian, S., and Eslamian, A., 2015, Water Reuse Guidelines for Agriculture, Urban Water Reuse Handbook, Ch. 14, Ed. By Eslamian, S., Taylor and Francis, CRC Group, USA, 177-186.

[49] Eslamian, A., Eslamian, F., and Eslamian, S., 2015, Water Reuse Guidelines for Industry, Urban Water Reuse Handbook, Ch. 15, Ed. By Eslamian, S., Taylor and Francis, CRC Group, USA, 187-194.

[50] Eslamian, S., Eslamian, F., and Eslamian, A., 2015, Water Reuse Guidelines for Recreation, Urban Water Reuse Handbook, Ch. 16, Ed. By Eslamian, S., Taylor and Francis, CRC Group, USA, 195-200.

[51] Banjoko, B. and Eslamian, S., 2015, Environmental Impact Assessment: An Application to Urban Water Reuse, Urban Water Reuse Handbook, Ch. 20, Ed. By Eslamian, S., Taylor and Francis, CRC Group, USA, 229-242.

[52] Banjoko, B. and Eslamian, S., 2015, Environmental Impact Assessment: An Application to Urban Water Reuse, Urban Water Reuse Handbook, Ch. 20, Ed. By Eslamian, S., Taylor and Francis, CRC Group, USA, 229-242.

[53] Amiri, M. J., Eslamian, S., Arshadi, M., and Khozaei, M., 2015, Water Recycling and Community, Urban Water Reuse Handbook, Ch. 22, Ed. By Eslamian, S., Taylor and Francis, CRC Group, USA, 261-274.

[54] Ferdaush, J., Noor Islam, Sh., Reinstädtler, S., and Eslamian, S., 2015, Ethical and Cultural Dimension of Water Reuse, Urban Water Reuse Handbook, Ch. 24, Ed. By Eslamian, S., Taylor and Francis, CRC Group, 285-296.

[55] Bazrkar, M. H., Zamani, N., and Eslamian, S., 2015, Evaluation of Socioeconomic Impacts of Urban Water Reuse Using System Dynamics Approach, Urban Water Reuse Handbook, Ch. 28, Ed. By Eslamian, S., Taylor and Francis, CRC Group, 331-340.

[56] Mujere, N. and Eslamian, S., 2015, Blackwater System, Urban Water Reuse Handbook, Ch. 33, Ed. By Eslamian, S., Taylor and Francis, CRC Group, 393-404.

[57] Abu-Ghunmi, L., and Eslamian, S., 2015, Graywater, Urban Water Reuse Handbook, Ch. 34, Ed. By Eslamian, S., Taylor and Francis, CRC Group,405-420.

[58] Eslamian, S., Amininezhad, S. M., and Amininejad, S. M., 2015, Contamination Warning System, Urban Water Reuse Handbook, Ch. 39, Ed. By Eslamian, S., Taylor and Francis, CRC Group, 481-488.

[59] Crusberg, T. C., and Eslamian, S., 2015, Choosing Indicators of Fecal Pollution for Wastewater Reuse Opportunities, Urban Water Reuse Handbook, Ch. 42, Ed. By Eslamian, S., Taylor and Francis, CRC Group, 511-520.

[60] Boogaard, F. and Eslamian, S , 2015, Wastewater Monitoring, Urban Water Reuse Handbook, Ch. 48, Ed. By Eslamian, S., Taylor and Francis, CRC Group, 583-586.

[61] Mujere, N., and Eslamian, S., 2015, Urban Wetland Hydrology and Water Purification, Urban Water Reuse Handbook, Ch. 50, Ed. By Eslamian, S., Taylor and Francis, CRC Group, 603-616.

[62] Nazif, S., and Eslamian , S., 2015, Urban Wetland Hydrology and Changes , Urban Water Reuse Handbook, Ch. 51, Ed. By Eslamian, S., Taylor and Francis, CRC Group, 617-640.

[63] Banjoko, B., and Eslamian, S., 2015, Phytoremediation, Urban Water Reuse Handbook, Ch. 53, Ed. By Eslamian, S., Taylor and Francis, CRC Group, 657-702.

[64] Rivas Hernández, A., Rivas Acosta, I., and Eslamian, S., .2015, Treatment Wetlands: Fundamentals, Urban Water Reuse Handbook, Ch. 54, Ed. By Eslamian, S., Taylor and Francis, CRC Group, 703-716.

[65] Rahman, A., and Eslamian, S., 2015, Rainwater Tanks as a Means of Water Reuse and Conservation in Urban Areas, Urban Water Reuse Handbook, Ch. 60, Ed. By Eslamian, S., Taylor and Francis, CRC Group, 797-808.

[66] Qian, Q., and Eslamian, S., 2015, Groundwater Recharge and Unconventional Water: Design and Management Criteria, Urban Water Reuse Handbook, Ch. 61, Ed. By Eslamian, S., Taylor and Francis, CRC Group, 809-816.

[67] Saket, R. K. and Eslamian, S., 2015, Use of Wastewater for Hydroelectric Power Generation, Urban Water Reuse Handbook, Ch. 63, Ed. By Eslamian, S., Taylor and Francis, CRC Group, 827-838. 
[68] Eslamian, S., Amininezhad, S. M., Amininejad, S. M., Adamowski, J., 2015, Application of Nanotechnology in Water Reuse, Urban Water Reuse Handbook, Ch. 64, Ed. By Eslamian, S., Taylor and Francis, CRC Group, 839-844.

[69] Perez Sierra, J. A. and Eslamian, S., 2015, Water Reuse in Coastal Areas, Urban Water Reuse Handbook, Ch. 67, Ed. By Eslamian, S., Taylor and Francis, CRC Group, 867-874.

[70] Perez Sierra, J. A. and Eslamian, S., 2015, Water Reuse in Coastal Areas, Urban Water Reuse Handbook, Ch. 67, Ed. By Eslamian, S., Taylor and Francis, CRC Group, 867-874.

[71] Noor Islam, Sh., Reinstädtler, S., and Eslamian, S., 2015, Water Reuse Sustainability in Cold Climate Regions, Urban Water Reuse Handbook, Ch. 68, Ed. By Eslamian, S., Taylor and Francis, CRC Group, 875-886.

[72] Rina, K., Eslamian, S., Tyagi, G., and Singh, N., 2015, Feasibility Studies for Water Reuse Systems,Urban Water Reuse Handbook, Ch. 71, Ed. By Eslamian, S., Taylor and Francis, CRC Group, 909, 926.

[73] Salequzzaman, MD., Tariqul Islam, S. M., Shiddiquzzaman, M., andEslamian, S., 2015. Climate Change Adaptation and Water Reuse, Urban Water Reuse Handbook, Ch. 75, Ed. By Eslamian, S., Taylor and Francis, CRC Group, 969-980.

[74] Kumar Goyal, M., Singh, V., and Eslamian, S., 2015, Impact of Climate Change on Drinking Water, Urban Water Reuse Handbook, Ch. 76, Ed. By Eslamian, S., Taylor and Francis, CRC Group, 981-1006.

[75] Hamdy, A. and Eslamian, S., 2015, Sustainable Reuse and Recycling of Treated Urban Wastewater, Urban Water Reuse Handbook, Ch. 80, Ed. By Eslamian, S., Taylor and Francis, CRC Group, 1039-1054.

[76] Thakur, J. K., Karmacharya, S., Singh, P., Gurung, D., and Eslamian, S., 2015, Water Reuse Products in Urban Areas, Urban Water Reuse Handbook, Ch. 81, Ed. By Eslamian, S., Taylor and Francis, CRC Group, 1055-1070.

[77] Eslamian, S., Sayahi, M., and Khosravi, B., 2015, Conjunctive Use of Water Reuse and Urban Water, Urban Water Reuse Handbook, Ch. 82, Ed. By Eslamian, S., Taylor and Francis, CRC Group, 1071-1078.

[78] Irfan, Z. B., and Eslamian, S., 2015, Urban Water Reuse Policy, Urban Water Reuse Handbook, Ch. 83, Ed. By Eslamian, S., Taylor and Francis, CRC Group, 1079-1096.

[79] Eslamian, S. and Motevallian, S. S.,2014, Sustainability in Urban Water System, in Handbook of Engineering Hydrology, Ch. 27, Vol. 1: Fundamentals and Applications, Ed. By Eslamian, S., Francis and Taylor, CRC Group, USA, 549-562.

[80] Mujere, N. and Eslamian, S. 2014, Impact of Urbanization on Runoff Regime, Chowdhury, R. K. andEslamian, S. 2014, Statistical Parameters Used for Assessing Hydrological Regime, in Handbook of Engineering Hydrology, Ch. 29, Vol. 2: Modeling, Climate Changes and Variability, Ed. By Eslamian, S., Francis and Taylor, CRC Group, USA, 605-615.

[81] Eslamian, S., Tarkesh Esfahany, S., Nasri, M. and Safamehr, M., 2013, Evaluating the potential of urban reclaimed water in area of north Isfahan, Iran, for industrial reuses, Int. J. Hydrology Science and Technology, Vol. 3, No. 3, 257-269.

[82] Biabanaki, M., Tabatabaei Naeini, A. and S. S. Eslamian, 2012, Effects of Urbanization on Stream Channels, Journal of Civil Engineering and Urbanism (JCEU), Vo. 2, No. 4, 136-142.

[83] Eslamian, S. S., Tarkesh, S., Kamran, M. R. and Y. Harooni, 2011, Evaluating The Potential of Urban Reclaimed Water in Area of North Isfahan, Iran, For Industrial Reuses, 4th international conference of water resource and sustainable development, Algeria.

[84] Eslamian, S. S., Tarkesh-Isfahany, S., 2011, Industrial reuse of urban wastewaters, a step towards sustainable development of water resources, $1^{\text {st }}$ International Conference on Desalination and Environment: A Water Summit, 29 Oct. 1 Nov., Beach Rotana, Abu Dhabi, UAE.

[85] Taebi, A., Eslamian, S. S. and M. Vashtani, 1999, Evaluation of Urban Runoff Quality Models, First Regional Conference on Water Balance, Khuzestan Water and Power Authority, Ahwaz, Iran, 393-402.

[86] Keshavarzy, A., Erskine W. D. and S. S. Eslamian, 1995, River Management Vs. Urban Development in the Hawkesbury-Nepean River Basin, Australia, Regional Conference on Water Resources Management, Isfahan University of Technology, Isfahan, Iran, 629-637.

[87] Taebi, A., Eslamian, S. S. and M. Vashtani, 2000, Evaluation of Urban Runoff Quality Models, First Regional Conference on Water Balance, Khuzestan Water and Power Authority, Ahwaz, Iran, 393-402.

[88] Shayannejad M, Eslamian S, Singh V.P., Ostad-Ali-Askari K, et al. 2017, Evaluation of Groundwater Quality for Industrial Using GIS in Mountainous Region of Isfahan Province, Koh-Payeh, Isfahan, Iran. International Journal of Constructive Research in Civil Engineering (IJCRCE), 3(3): 24-37.

[89] Ostad-Ali-Askari K, Eslamian S, Shayannejad M, et al. Groundwater Hydrodynamic. Horoufchin Publisher. First Edition, 2016. ISBN: 978-600-7419-53-3. Isfahan, Iran. 
Investigation of Lands Cover Changes with Emphasis on Isfahan Urban Green Space using Manuscripts Tissues, Isfahan, Iran

[90] Godarzi A, Eslamian S, Ostad-Ali-Askari K. Water in Literature Aspects (Social and Cultural Aspects). Publication of Tehran Municipality. First Edition, 2016. ISBN: 978-600-439-096-5. Tehran, Iran.

[91] Ostad-Ali-Askari K, Shayannejad M, Golabchian M. Numerical methods in groundwater. Kankash publisher. First edition, 2015. ISBN: 978-600-136-276-7. Isfahan, Iran.

[92] Ostad-Ali-Askari K. Nitrate pollution in groundwater. Horoufchin publisher, First Edition, 2015. ISBN: 978-600-7419-23-6. Isfahan, Iran.

[93] Ostad-Ali-Askari K. Nitrate pollution in groundwater. Horoufchin publisher, First Edition, 2015. ISBN: 978-600-7419-23-6. Isfahan, Iran.

[94] Shayannejad M, Ostad-Ali-Askari K. Optimization and its application in water resources management. Kankash publisher. First edition, 2015. ISBN: 978-600-136-248-4. Isfahan, Iran.

[95] Shayannejad M, Ostad-Ali-Askari K. Modeling of solute movement in groundwater. Kankash publisher. First edition, 2015. ISBN: 978-600-136-256-9. Isfahan, Iran.

[96] Ostad-Ali-Askari K. Groundwater. Horoufchin publisher, First Edition, 2015. ISBN: 978-600-7419-33-5. Isfahan, Iran.

[97] Ostad-Ali-Askari K, Shayannejad M, Eslamian S, et al. 2017, Deficit Irrigation: Optimization Models. Management of Drought and Water Scarcity. Handbook of Drought and Water Scarcity, Taylor \& Francis Publisher, USA. Vol. 3. $1^{\text {th }}$ Edition, pp: 373-389.

\section{AUTHORS' BIOGRAPHY}

Zahra Ghasemi-Siani, Department of Remote Sensing,Yazd Branch, Islamic Azad University, Yazd, Iran.

Mojtaba Pirnazar, Department of Remote Sensing, Tabriz University, Tabriz, Iran

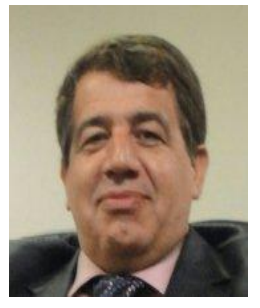

Professor Saeid Eslamian, is a full professor of water system engineering in the Department of Water Engineering at Isfahan University of Technology, Iran, where he has been since 1995. He received his $\mathrm{PhD}$ from Civil and Environmental Engineering School, University of New South Wales, Sydney, Australia, under the supervision of Professor David Pilgrim. His research focuses mainly on water resources planning, management, and sustainability and statistical and environmental hydrology in a changing climate. Formerly, he was a visiting professor at Princeton University, New Jersey, and University of ETH Zurich, Switzerland. On the research side, he started a research partnership in 2014 with McGill University, Montreal, Quebec, Canada. He has contributed to more than 600 publications in journals, books, or as technical reports. $\mathrm{He}$ is the founder and chief editor of both the International Journal of Hydrology Science and Technology (Scopus, Inderscience) and the Journal of Flood Engineering. Professor Eslamian is also associate editor of the Journal of Hydrology (Elsevier) and Ecohydrology and Hydrobiology (Elsevier). He has authored more than 150 book chapters and books. Recently, Professor Eslamian published eight handbooks with Taylor \& Francis Group (CRC Press) as chief editor: a three-volume Handbook of Engineering Hydrology (2014), Urban Water Reuse Handbook (2015), a three-volume Handbook of Drought and Water Scarcity (2017), and Underground Aqueducts Handbook (2016).

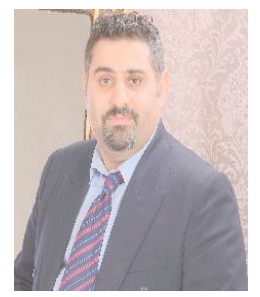

Dr. Kaveh Ostad-Ali-Askari, is a $\mathrm{PhD}$ of civil engineering, Department of Water Resources Engineering, Faculty of Civil Engineering. He collaborates as Editorial Board Membership in more than 45 Journals and as reviewers in more than 35 Journals. Currently, Associate, Editor-in-Chief of IJREH. He has contributed to more than 125 publications in Journals, Books and Technical Reports. He was a Visiting Assistant Professor at Canadian University Dubai, and American University in Dubai. On the research side, he started a research partnership in 2017 with Concordia University in Montreal, Quebec, Canada.

His topics of interest include Groundwater Hydrology, Irrigation and Drainage Engineering, Sustainable Development and Environmental Assessment, Climate and Integrated and Sustainable Water Resource Management, Water System Engineering, Water Resources Planning, Artificial Neural Network, and Genetic Algorithm. Currently, he is a Faculty Member of the Department of Civil Engineering, Isfahan(Khorasgan) Branch, Islamic Azad University, Iran.

Mahboubeh Amoushahi-Khouzani, Water Engineering Department, Science and Research Branch, Islamic Azad University, Tehran, Iran. 


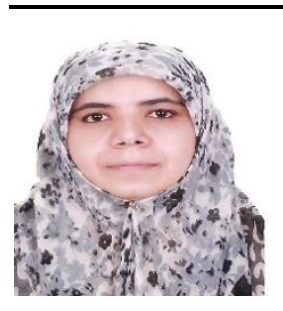

Maryam Marani-Barzani, Department of Geography, University of Malaya (UM),50603 Kuala Lumpur, Malaysia.Member of Suggestion Committee in Ministerial of Education in Iran(2002-2007).Member of Research on Heat Sink Capability of Inland Water Resources for Thermal Power Plants in Peninsular Malaysiaproject (TNBR)(2014-2015).Member of Board Trustees at Consultant Engineering Company (SharsazanZendeh Rood) in Iran.(2015-peresent).

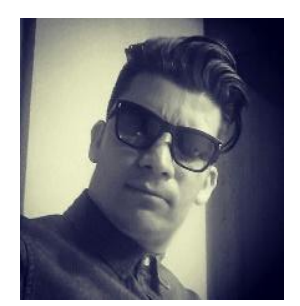

Morteza Soltani, Department of Architectural Engineering, Shahinshahr Branch, Islamic Azad University, Shahinshahr, Iran.

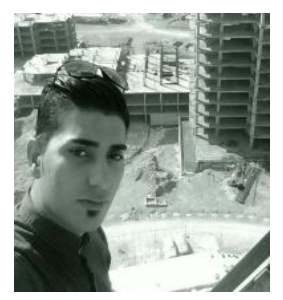

Masoud Kazemi, M.Sc. student of Civil Engineering, Civil Engineering Department, Najafabad Branch, Islamic Azad University, Iran.He has been an expert in various projects of Civil Engineering and technical software such as AutoCAD and MATLAB $®$ programming

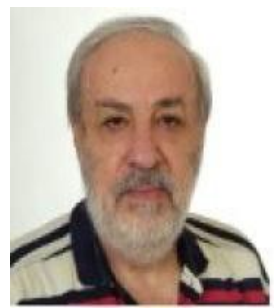

Professor Nicolas R. Dalezios, is a professor of agro-meteorology and remote sensing, University of Thessaly, Volos Hellas; president of the Council of the Agricultural University of Athens, Hellas; and professor and founding director of the Laboratory of Agro-meteorology, University of Thessaly, Volos Hellas (19912011). He has done his postgraduate studies in meteorology (Athens, 1972) and hydrological engineering (University of Delft, 1974) and his $\mathrm{PhD}$ in civil engineering (University of Waterloo, Canada, 1982). He has a longstanding research record in agro-meteorology, agro-hydrology, remote sensing, modeling, environmental hazards, risk assessment, climate variability/change. He is the author or co-author in over 280 refereed publications and technical and scientific publications, member of editorial boards and reviewer in international scientific journals, editor or co-editor in over 15 edited publications, and co-author in about 30 book chapters.

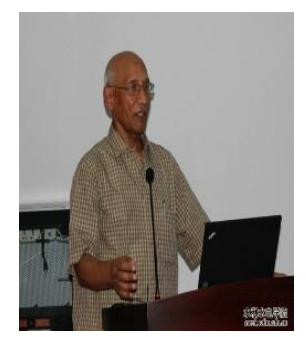

Professor Vijay P. Singh, Ph.D., D.Sc., D. Eng. (Hon.), Ph.D. (Hon.), D.Sc. (Hon.), P.E., P.H., Hon. D. WRE, Academician (GFA),Distinguished Professor, Regents Professor, Caroline and William N. Lehrer Distinguished Chair in Water Engineering

President, FARA, President, G.B.S. Board, Editor-in-Chief, Water Science and Technology Library Book series, Editor, Global Water Resources Book Series, Editor-in-Chief, Journal of Ground Water Research, Editor-in-Chief, Open Agriculture, Editor, Journal of Agricultural Research, Department of Biological and Agricultural Engineering \&Zachry Department of Civil Engineering, Texas A and M University. is a professor of agro-meteorology and remote sensing, University of Thessaly, Volos Hellas; president of the Council of the Agricultural University of Athens, Hellas; and professor and founding director of the Laboratory of Agro-meteorology, University of Thessaly, Volos Hellas (1991-2011). He has done his postgraduate studies in meteorology (Athens, 1972) and hydrological engineering (University of Delft, 1974) and his PhD in civil engineering (University of Waterloo, Canada, 1982). He has a longstanding research record in agro-meteorology, agro-hydrology, remote sensing, modeling, environmental hazards, risk assessment, climate variability/change. He is the author or co-author in over 290 refereed publications and technical and scientific publications, member of editorial boards and reviewer in international scientific journals, editor or co-editor in over 20 edited publications, and co-author in about 35 book chapters. 


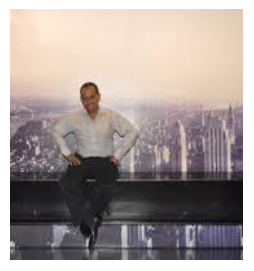

Dr. Yohannes Yihdego, Snowy Mountains Engineering Corporation (SMEC), Sydney, New South Wales 2060, Australia. GeoInformation Science and Earth Observation (ITC), University of Twente, the Netherlands.

Working at Global Engineering consulting firm in Hydro-Geo-Engineering across Australia, Middle East, Asia, Africa in water, resource, mining, infrastructure, transport, energy, agriculture, landfill, contamination/pollution/remediation, environmental assessments, flood/urban drainage design/modelling, drought, climate change Produced hundreds' of Engineering technical -feasibility/ detail design reports \& Published several articles \& book chapters Serving as peer Reviewer \& Editor board member.

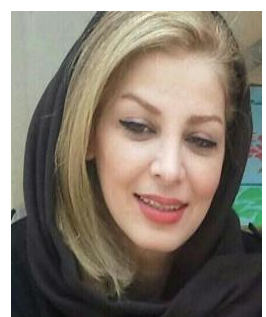

Foroozan Rajaei-Rizi, Water Engineering Department, Shahrekord University, Shahrekord, Iran.

Shahide Dehghan, Department of Geography, Najafabad Branch, Islamic Azad University, Najafabad, Iran.

Hossein Norouzi, Department of Civil Engineering, Maybod Branch, Islamic Azad University, Maybod, Yazd, Iran.

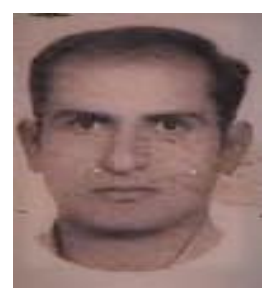

Hamid-Reza Shirvani-Dastgerdi, Department of Civil Engineering,

Isfahan (Khorasgan) Branch, Islamic Azad University, Isfahan, Iran.

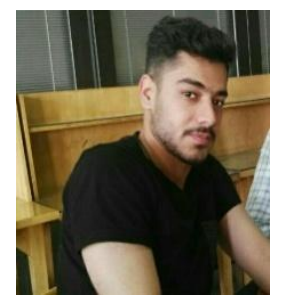

Arsalan Malekian, Department of Civil Engineering, Isfahan (Khorasgan) Branch, Islamic Azad University, Isfahan, Iran.

Citation: Dr. Kaveh Ostad-Ali-Askari et al. (2017). Investigation of Lands Cover Changes with Emphasis on Isfahan Urban Green Space using Manuscripts Tissues, Isfahan, Iran, International Journal of Modern Studies in Mechanical Engineering (IJMSME), 3(3), pp.26-39, DOI: http://dx.doi.org/10.20431/24549711.0303004.

Copyright: (@ 2017 Dr. Kaveh Ostad-Ali-Askari This is an open-access article distributed under the terms of the Creative Commons Attribution License, which permits unrestricted use, distribution, and reproduction in any medium, provided the original author and source are credited 